\title{
Article \\ 4-Hexylresorcinol Inhibits Class I Histone Deacetylases in Human Umbilical Cord Endothelial Cells
}

\author{
Jwa-Young Kim ${ }^{1} \mathbb{D}$, Hae-Yong Kweon ${ }^{2}$, Dae-Won $\mathrm{Kim}^{3}{ }^{\mathbb{D}}$, Je-Yong Choi ${ }^{4} \mathbb{D}$ and Seong-Gon $\mathrm{Kim}^{5, * \mathbb{D}}$ \\ 1 Department of Dentistry (Oral and Maxillofacial Surgery), Hallym University Kangnam Sacred Heart \\ Hospital, Hallym University Medical Center, 1 Singil-ro, Yeongdeungpo-gu, Seoul 07441, Korea; \\ jwayoung@hanmail.net \\ 2 Sericultural and Apicultural Division, National Institute of Agricultural Science, Rural Development \\ Administration, Wanju 55365, Korea; hykweon@korea.kr \\ 3 Department of Biochemistry and Molecular Biology, College of Dentistry, Gangneung-Wonju National \\ University, Gangneung 28644, Korea; kimdw@gwnu.ac.kr \\ 4 Skeletal Diseases Analysis Center, Korea Mouse Phenotyping Center, Department of Biochemistry and Cell \\ Biology, Cell and Matrix Research Institute, School of Medicine, Kyungpook National University, \\ Daegu 41944, Korea; jechoi@knu.ac.kr \\ 5 Department of Oral and Maxillofacial Surgery, College of Dentistry, Gangneung-Wonju National University, \\ Gangneung 28644, Korea \\ * Correspondence: kimsg@gwnu.ac.kr; Tel.: +82-336-402-468
}

check for updates

Citation: Kim, J.-Y.; Kweon, H.-Y.; Kim, D.-W.; Choi, J.-Y.; Kim, S.-G 4-Hexylresorcinol Inhibits Class I Histone Deacetylases in Human Umbilical Cord Endothelial Cells. Appl. Sci. 2021, 11, 3486. https:// doi.org/10.3390/app11083486

Academic Editor: Francesca Silvagno

Received: 16 March 2021

Accepted: 12 April 2021

Published: 13 April 2021

Publisher's Note: MDPI stays neutral with regard to jurisdictional claims in published maps and institutional affiliations.

Copyright: (C) 2021 by the authors. Licensee MDPI, Basel, Switzerland. This article is an open access article distributed under the terms and conditions of the Creative Commons Attribution (CC BY) license (https:// creativecommons.org/licenses/by/ $4.0 /)$.
Featured Application: Histone deacetylase inhibitor has broad spectrum therapeutic merits. This study demonstrated that 4-hexylresorcinol was a novel histone deacetylase inhibitor.

\begin{abstract}
Histone deacetylases (HDACs) are key enzymes for post-translational modification and influence on various cellular activities. Thus, HDACs are associated with many diseases and their inhibitors have clinical significance. Here, 4-Hexylresorcinol (4HR) was studied as an inhibitor for class I HDACs using the HDAC inhibitor (HDACi) Trichostatin-A as a positive control. The 4HR was administered 1-100 $\mu \mathrm{M}$ to human umbilical endothelial cells (HUVECs) and the HDAC expression and activity were examined. The $4 \mathrm{HR}$ decreased the expression level of HDAC1, 3, 4, and 5 in a time and dose-dependent manner. The $4 \mathrm{HR}$ also increased acetylated lysine and decreased HDAC activity significantly $(p<0.05)$. Collectively, $4 \mathrm{HR}$ was a new class I HDAC inhibitor that reduced the expression and activity of HDAC in HUVECs.
\end{abstract}

Keywords: 4-hexylresorcinol; histone deacetylase; mitochondria; ATP

\section{Introduction}

Histone deacetylase (HDAC) is an enzyme for removing the acetyl group from lysine in the protein [1]. Many types of proteins have lysine as their amino acid. Adding or removing the acetyl group from lysine is a post-translational modification of the protein and affects protein conformation and function [2]. DNA has a strong negative charge because of phosphate groups. Acetylated histone loses its positive charge and relaxes the binding between histone and DNA. Accordingly, acetylation and deacetylation of histone can regulate specific gene transcription [1,2]. Except for histone, the function of the other proteins is also influenced by HDAC as a post-translational modification process [2]. There are several types of HDACs in 4 classes (Table 1). Their intracellular localizations are various according to their functional demands. The main localizations for HDACs are the nucleus and mitochondria [1].

Considering its profound implications in cellular function, class I HDACs are involved in many types of physiological processes and diseases such as cardiovascular disease, autoimmune disease, musculoskeletal disease, and malignancy $[1,3,4]$. HDAC1 regulates gene expression and its expression is elevated in transformed cells [5]. HDAC2 is overexpressed 
in pancreatic cancer [6]. The overexpression of HDAC2 is also observed in pathologic cardiomegaly [7]. A representative broad-spectrum HDAC inhibitor (HDACi)-trichostatin A (TSA) inhibits cardiac hypertrophy [8]. TSA is also used for the treatment of established cardiac hypertrophy [9]. The administration of HDACi is helpful for muscle regeneration in muscle dystrophy [10]. Valproic acid was originally developed as an anti-convulsant and HDACi. Valproic acid improves nerve regeneration and motor function in the damaged rat model [11]. TSA treats rheumatism by suppressing the expression level of tumor necrosis factor- $\alpha$ (TNF- $\alpha$ ) and interleukin-6 (IL-6) [12]. Butyrate is an organic chemical of bacterial origin and HDACi [13]. The administration of butyrate reduces pain in epileptic rats [13] and inhibits the proliferation of colorectal cancer cells [4].

Table 1. Classification of HDAC.

\begin{tabular}{cc}
\hline Class & Members \\
\hline I & HDAC1, 2, 3, 8 \\
IIA & HDAC4, 5, 7, 9 \\
IIB & HDAC6, 10 \\
III & SIRT1, 2, 3, 4, 5, 6, 7 \\
IV & HDAC11 \\
\hline
\end{tabular}

HDAC: histone deacetylase, SIRT: sirtuin.

Resorcinolic lipid is an organic chemical of bacterial origin [14]. The substance 4-Hexylresorcinol (4HR) is a synthetic resorcinolic lipid and has been developed as an antiseptic agent [14]. The 4HR suppresses the respiration of micro-organisms and induces dormancy [15]. The long alkyl group of $4 \mathrm{HR}$ binds to tyrosinase effectively and inhibits enzyme activity [16]. Accordingly, $4 \mathrm{HR}$ can be used to prevent melanosis of food [16]. As it is considered as a food additive, toxicological studies have been widely done. In these studies, anticancer effects have been found $[17,18]$. Based on these results, the detailed anticancer mechanisms of $4 \mathrm{HR}$ have been investigated $[19,20]$. The $4 \mathrm{HR}$ suppresses the nuclear factor- $\mathrm{KB}(\mathrm{NF}-\mathrm{kB})$ pathway by inhibiting transglutaminase-2 (TG-2) in oral cancer cells $[19,21]$. Unlike oral cancer cells, $4 \mathrm{HR}$ administration reduces the formation of foreign body giant cells in the silk-based graft material [22] and suppresses TNF- $\alpha$ expression in a deep burn [23]. Recently, 4 HR has been identified as a potent M2 macrophage polarizing agent [24]. Transforming growth factor- $\beta 1$ (TGF- $\beta 1$ ) is increased by $4 \mathrm{HR}$, while decreasing TNF- $\alpha$ expression in RAW263.7 cells [25], and the expression level of vascular endothelial cell growth factor (VEGF) is increased by $4 \mathrm{HR}$ via the TGF- $\beta 1$ mediated pathway in human umbilical endothelial cells (HUVECs) [26]. During investigation of the mechanism of TGF- $\beta 1$ expression by $4 \mathrm{HR}$ administration, we found that the broad function of $4 \mathrm{HR}$ might be similar to that of HDACi. The $4 \mathrm{HR}$ has a hydrophobic alkyl group [14] and the length of the alkyl group is similar to that of the functional group in other HDACi [27]. Though $4 \mathrm{HR}$ does not have an acetyl group at the end of the hexyl group, hydroxyl-benzene can do the role as a cap group. Therefore, the possibility of HDACi for $4 \mathrm{HR}$ is highly probable.

The purposes of this study were to clarify $4 \mathrm{HR}$ as Class I HDACi in HUVECs. Class I HDAC (HDAC1 and 3) and class IIA HDAC (HDAC4 and 5) expression levels and acetylated lysine level were evaluated by Western blot. For comparison purposes, TSA was treated and the expression levels of $\mathrm{HDAC} 1,3,4$, and 5 and Ac-lys were investigated. The enzymatic activity of Class I HDAC was also investigated after 4HR administration.

\section{Materials and Methods}

\subsection{HUVEC Culture}

HUVECs (Lonza, Walkersville, MD, USA) were cultured as previously described in our publications $[28,29]$. The medium was endothelial cell growth medium-2 (Clonetics, Lonza). Cells were cultured in $\mathrm{CO}_{2}$ incubator. To prevent mycoplasma contamination, tests were done on a regular basis. 


\subsection{Western Blot and HDAC Inhibitory Assay}

When HUVECs were grown, approximately $70 \%$ confluent, the cells were treated with 1, 10, and $100 \mu \mathrm{M} 4 \mathrm{HR}$ for 2,8 , or $24 \mathrm{~h}$; control cells were treated with $1 \mathrm{~mL}$ of normal saline. TSA known HDACi was purchased from Sigma-Aldrich (CAT\#: T8552, St. Louis, MO, USA). TSA inhibits HDAC1, HDAC4, and HDAC6 and $\mathrm{IC}_{50}$ is $6 \mathrm{nM}$, $38 \mathrm{nM}$, and $8.6 \mathrm{nM}$, respectively [27]. Accordingly, 1, 10, and $100 \mathrm{nM}$ TSA were applied for $24 \mathrm{~h}$. According to the datasheet from the manufacturer, $\mathrm{IC}_{50}$ for TSA was announced as $20 \mathrm{nM}$. The expression of TGF- $\beta 1$ and apoptosis-inducing factor (AIF) was increased by $4 \mathrm{HR}$ administration $[26,28]$. The expression changes of TGF- $\beta 1$ and AIF after $20 \mathrm{nM}$ TSA application were also investigated. Cultured cells were harvested with protein lysis buffer (PRO-PREP, iNtRON Biotechnology Inc., Sungnam, Korea) and underwent Western blotting for HDAC1, HDAC3, HDAC4, HDAC5, and Ac-lys. Antibodies for HDACs, TGF- $\beta 1$, AIF, and Ac-lys were purchased from SantaCruz Biotechnology (Santa Cruz, CA, USA). The quantification of the proteins was done as described previously [28,29].

To assess the effect of $4 \mathrm{HR}$ administration on HDAC enzyme activity, 1, 10, and $100 \mu \mathrm{M}$ of $4 \mathrm{HR}$ were applied and cellular lysates were collected after 2, 8, and $24 \mathrm{~h}$. A subsequent procedure was done with a commercially available kit (CAT: ab156064, Abcam, Cambridge, UK). This kit can measure the activity of HDAC1, 2, 3, and 8 (Class I HDAC) according to the product datasheet. After the preparation of samples, HDAC assay buffer and substrate were placed into the reaction wells. Inhibitor and developer were added to wells and mixed thoroughly. The prepared samples were added to each well and incubated for $20 \mathrm{~min}$ at room temperature. Then, stop solution was added and incubated for $10 \mathrm{~min}$ at room temperature. The fluorescence intensity was measured by plate reader.

\section{Results}

\subsection{HR Decreased HDAC Expression and Increased Ac-Lys}

The administration of 1 to $100 \mu \mathrm{M} 4 \mathrm{HR}$ decreased the expression of HDAC1, 3, 4, and 5 in HUVECs (Figure 1a). If HDAC activity is reduced, acetylated lysine (Ac-lysine) will be increased [1]. Accordingly, the administration of 1 to $100 \mu \mathrm{M} 4 \mathrm{HR}$ increased the expression of Ac-lysine in HUVECs (Figure 1b). TSA is known as broad-spectrum HDACi [30]. The expression changes of HDACs and Ac-lysine after administration of TSA were examined to compare them to those of $4 \mathrm{HR}$ administration. The administration of TSA decreased the expression of HDAC1, 3, 4, and 5 in HUVECs (Figure 2a). The administration of 1 to $100 \mathrm{nM}$ TSA increased the expression of Ac-lysine in HUVECs (Figure 2b).

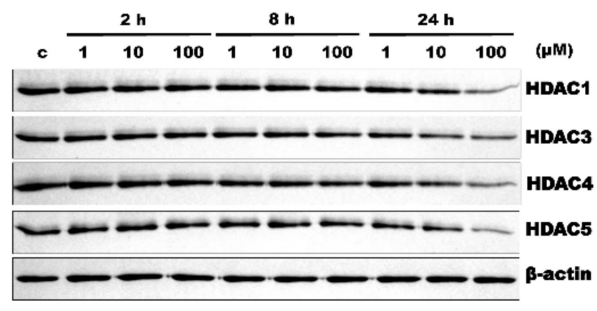

(a)

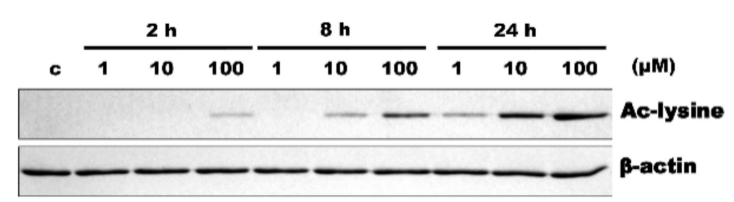

(b)

Figure 1. Western blot analysis. (a) The administration of $4 \mathrm{HR}$ decreased the expression of HDACs in HUVECs. The densitometric measurements are shown in Figure S1. (b) The administration of 4HR increased the expression of Ac-lysine in HUVECs. The densitometric measurements are shown in Figure S2. 


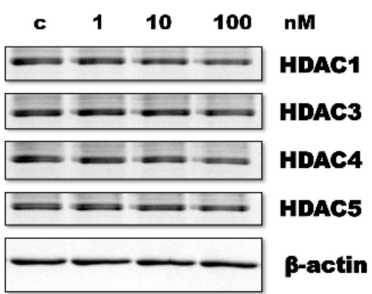

(a)

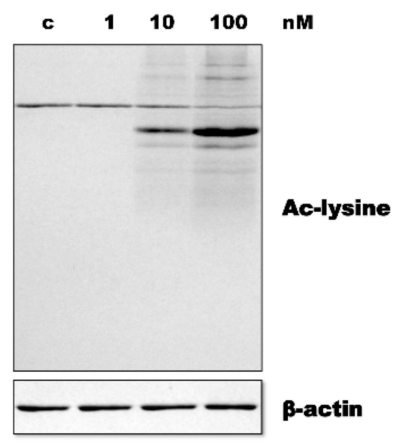

(b)

Figure 2. Western blot analysis. (a) The administration of TSA slightly decreased the expression of HDACs in HUVECs. (b) The administration of TSA increased the expression of Ac-lysine in HUVECs.

The administration of $20 \mathrm{nM}$ TSA did not significantly change the expression of TGF$\beta 1$ in HUVECs (Figure 3a). The administration of $20 \mathrm{nM}$ TSA increased the expression of AIF in HUVECs (Figure 3b).



(a)

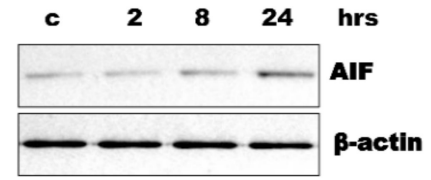

(b)

Figure 3. Western blot analysis after $20 \mathrm{nM}$ TSA application. (a) The administration of $20 \mathrm{nM}$ TSA did not increase the expression of TGF- $\beta 1$ prominently in HUVECs. (b) The administration of $4 \mathrm{HR}$ increased the expression of AIF in HUVECs.

\subsection{HR Inhibited Class I HDAC Activity in HUVECs}

The administration of 1 to $100 \mu \mathrm{M} 4 \mathrm{HR}$ decreased the enzyme activity of HDACs in HUVECs (Figure 4). HDAC enzyme activity was decreased significantly in 10 and $100 \mu \mathrm{M}$ $4 \mathrm{HR}$ administration at $8 \mathrm{~h}$ and $24 \mathrm{~h}(p<0.05)$.

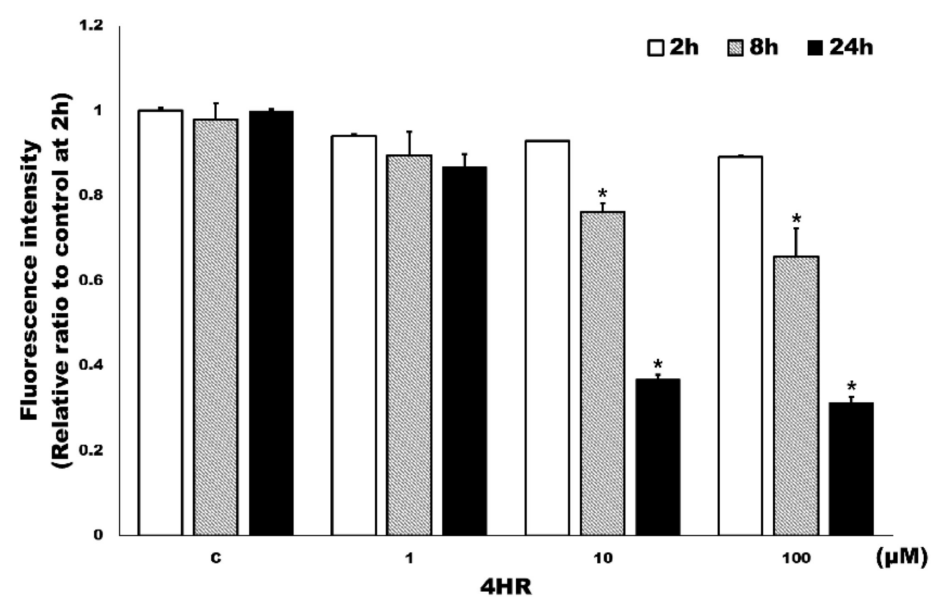

Figure 4. Enzyme inhibition assay. The administration of $4 \mathrm{HR}$ decreased HDAC enzyme activity ( ${ }^{*} p<0.05$ compared to the control group).

\section{Discussion}

In our previous study, $4 \mathrm{HR}$ had wide functions such as antimicrobial effects, anticancer effects, proangiogenic effects, anti-inflammatory effects, increasing calcification, and reducing metabolism. These divergent effects should be related to the broad spectrum regulation of cellular events. HDACs are key enzymes in post-translational modifications 
for the epigenetic regulation of various cellular events. In this study, we found the $4 \mathrm{HR}^{\prime} \mathrm{s}$ role as an HDACi and that 4HR decreased the expression level of HDAC1, 3, 4, and 5 in HUVECs. (Figure 1a). In addition, HDAC's enzyme activity was decreased by $4 \mathrm{HR}$ administration (Figure 4). With inhibition of HDAC expression and activity by $4 \mathrm{HR}$, Ac-lys is increased dose and time-dependently by $4 \mathrm{HR}$ administration (Figure 1b). This inhibitory effect on HDACs was comparable to those of TSA (known HDACi) (Figure 2). To our best knowledge, this was the first study of $4 \mathrm{HR}$ as novel HDACi.

In our previous study, 4HR increased the expression level of AIF in HUVECs [28,29]. In this study, TSA increased the expression level of AIF in HUVECs, too (Figure 3b). However, increased AIF expression by TSA did not result in the increasing TGF- $\beta 1$ expression (Figure 3a). Though $\mathrm{IC}_{50}$ of TSA is $<38 \mathrm{nM}$, a decreased expression level of cyclin A was observed at $10 \mu \mathrm{M}$ TSA administration [27]. As 1-100 nM TSA was used in this study, the increasing TGF- $\beta 1$ expression might be observed in a much higher concentration of TSA. Interestingly, $0.3 \mu \mathrm{M}$ TSA administration increased TGF $\beta$ type II receptor expression [31]. As the expression level of AIF was observed in $20 \mathrm{nM}$ TSA application, it looked evident that expression level of TGF- $\beta 1$ might not be directly associated with AIF expression. Sp1 is a transcription factor for TGF- $\beta 1$ and its expression is increased by butyrate-another kind of HDACi [32]. Interestingly, 4HR also increases Sp1 expression in SCC-9 cells [20]. Therefore, increased TGF- $\beta 1$ expression by $4 \mathrm{HR}$ administration might be associated with its HDACi activity and subsequent promotion of Sp1 expression.

Every HDAC has a hydrophobic pocket as its enzymatic domain. The $4 \mathrm{HR}$ has a long alkyl group and is strongly hydrophobic [14]. Therefore, $4 \mathrm{HR}$ might be a decoy molecule which could block the hydrophobic enzymatic domain (Figure 5). TSA has a six carbon chain for inserting the hydrophobic pocket of HDAC (Figure 5) and its derivatives also have a similar structure [27]. The 4 HR has a six carbon alkyl group, but does not have an acetyl group at the end of alkyl chain [14]. The binding affinity of $4 \mathrm{HR}$ on each HDAC might be influenced by its own structure. As 4HR does not have acetyl group, the binding affinity to HDAC might be weaker than TSA or its derivatives. Actually, TSA showed its HDACi activity at a much lower concentration than 4HR (Figures 1 and 2). Adding an acetyl or amine group to $4 \mathrm{HR}$ might be an interesting approach for novel HDACi development. In the search for novel HDACi, TSA derivatives having carboxylic acid group have $100 \mathrm{nM}$ as $\mathrm{IC}_{50}$, however, TSA derivatives having acetylated lysine have $31 \mu \mathrm{M}$ as $\mathrm{IC}_{50}$ [27]. Hydroxyl-benzene group might do its role as cap (Figure 5). TSA inhibits angiogenesis by suppressing hypoxia-inducible factor- $1 \alpha(\mathrm{HIF} 1 \alpha)$ [33]. However, $4 \mathrm{HR}$ increases angiogenesis via the HIF1 $\alpha$-independent pathway [34]. Though $4 \mathrm{HR}$ is known as an antiseptic, the administration of $4 \mathrm{HR}$ on a microorganism reduces the metabolic rate and does the role as a chemical chaperone [14]. Accordingly, the surviving microorganism undergoes dormancy [15]. The microorganism in the state of dormancy extremely reduces its metabolic rate and resists environmental stress [15]. Based on these observations, $4 \mathrm{HR}$ in eukaryotes may be mimicking the action in the prokaryotes. Though cellular dormancy in eukaryote is hardly defined, the dormancy-inducing property of $4 \mathrm{HR}$ may be beneficial for cancer treatment. Interestingly, the anticancer effect of $4 \mathrm{HR}$ was identified during its toxicology study by National Toxicology Program (NTP) team [18].

In this study, the HDACi activity of $4 \mathrm{HR}$ was much lower than that of TSA. As the function of HDAC is broad, its inhibition should be tailored to the intended purpose. The complete knock-out of HDAC1 and 3 is lethal in the embryonic period $[35,36]$. Pharmacological inhibition of HDAC has many benefits over genetic deletion such as reversible and incomplete inhibition [2]. The 4HR might be less potent for anticancer purposes than TSA. However, 4HR might have more advantages for wound healing acceleration or treatment of metabolic disease than TSA. Recently, a Chinese team found that $4 \mathrm{HR}$ administration increases bone mineral density in the osteoporosis animal model [37]. 


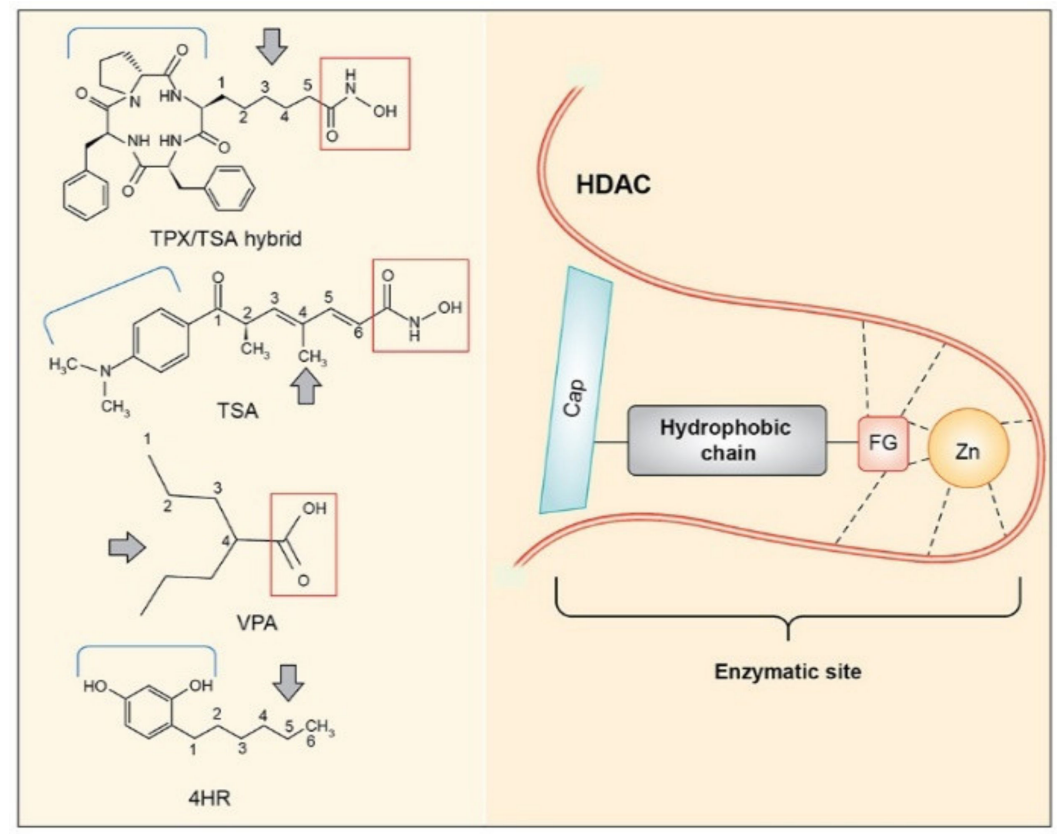

Figure 5. Model of $4 \mathrm{HR}$ action as a histone deacetylase inhibitor (HDACi). As the enzymatic site of HDACs is a deep hydrophobic pocket, HDACi has a hydrophobic group (arrows). The functional group (FC, red rectangle) allows hydrogen bonds (dotted lines) with zinc ions and surrounding amino acids. The cap (sky blue) is for blocking the pore to prevent the entrance of acetylated proteins. Trapoxin (TPX), trichostatin A (TSA) hybrid, and TSA have all three groups. Valproic acid (VPA) has a hydrophobic chain and functional group. The 4 HR has a cap and hydrophobic chain.

\section{Conclusions}

Collectively, 4HR was found to be novel HDACi. The 4HR inhibited class I HDAC activity and their protein expression. Considering functional divergence of HDAC, the therapeutic effect of $4 \mathrm{HR}$ administration should be studied independently according to its target disease.

Supplementary Materials: The following are available online at https://www.mdpi.com/article/ 10.3390/app11083486/s1, Figure S1: Relative expressions of histone deacetylase (HDAC) after 4-hexylresorcinol administration, Figure S2: Relative expressions of acetylated lysine after 4-hexylresorcinol administration.

Author Contributions: Conceptualization, J.-Y.K. and S.-G.K.; methodology, D.-W.K. and S.-G.K.; validation, D.-W.K. and J.-Y.C.; formal analysis, H.-Y.K.; investigation, D.-W.K.; data curation, J.-Y.C.; writing—original draft preparation, S.-G.K.; writing—review and editing, J.-Y.K. and J.-Y.C.; supervision, J.-Y.C.; funding acquisition, S.-G.K. All authors have read and agreed to the published version of the manuscript.

Funding: This study was carried out with the support of the "Cooperative Research Program for Agriculture Science and Technology Development (Project no. PJ01562601)" Rural Development Administration, Republic of Korea.

Institutional Review Board Statement: Not applicable.

Informed Consent Statement: Not applicable.

Data Availability Statement: There was no publicly archived datasets in this study.

Conflicts of Interest: The authors declare no conflict of interest. 


\section{References}

1. Haberland, M.; Montgomery, R.L.; Olson, E.N. The Many Roles of Histone Deacetylases in Development and Physiology: Implications for Disease and Therapy. Nat. Rev. Genet. 2009, 10, 32-42. [CrossRef]

2. Aka, J.A.; Kim, G.W.; Yang, X.J. Histone Deactylases: The Biology and Clinical Implication; Springer: New York, NY, USA, 2011; pp. 1-12. ISBN 978-3-642-21630-5.

3. Reichert, N.; Choukrallah, M.A.; Matthias, P. Multiple Roles of Class I HDACs in Proliferation, Differentiation, and Development. Cell Mol. Life Sci. 2012, 69, 2173-2187. [CrossRef]

4. Hajjar, R.; Richard, C.S.; Santos, M.M. The Role of Butyrate in Surgical and Oncological Outcomes in Colorectal Cancer. Am. J. Physiol. Gastrointest. Liver Physiol. 2021. [CrossRef]

5. Bartl, S.; Taplick, J.; Lagger, G.; Khier, H.; Kuchler, K.; Seiser, C. Identification of Mouse Histone Deacetylase 1 as a Growth Factor-Inducible Gene. Mol. Cell Biol. 1997, 17, 5033-5043. [CrossRef]

6. Fritsche, P.; Seidler, B.; Schuler, S.; Schnieke, A.; Gottlicher, M.; Schmid, R.M.; Saur, D.; Schneider, G. HDAC2 Mediates Therapeutic Resistance of Pancreatic Cancer Cells via the BH3-Only Protein NOXA. Gut 2009, 58, 1399-1409. [CrossRef]

7. Trivedi, C.M.; Luo, Y.; Yin, Z.; Zhang, M.; Zhu, W.; Wang, T.; Floss, T.; Goettlicher, M.; Noppinger, P.R.; Wurst, W.; et al. Hdac2 Regulates the Cardiac Hypertrophic Response by Modulating Gsk3 Beta Activity. Nat. Med. 2007, 13, 324-331. [CrossRef]

8. Kook, H.; Lepore, J.J.; Gitler, A.D.; Lu, M.M.; Wing-Man, Y.W.; Mackay, J.; Zhou, R.; Ferrari, V.; Gruber, P.; Epstein, J.A. Cardiac Hypertrophy and Histone Deacetylase-Dependent Transcriptional Repression Mediated by the Atypical Homeodomain Protein Hop. J. Clin. Investig. 2003, 112, 863-871. [CrossRef]

9. Kee, H.J.; Sohn, I.S.; Nam, K.I.; Park, J.E.; Qian, Y.R.; Yin, Z.; Ahn, Y.; Jeong, M.H.; Bang, Y.J.; Kim, N.; et al. Inhibition of Histone Deacetylation Blocks Cardiac Hypertrophy Induced by Angiotensin II Infusion and Aortic Banding. Circulation 2006, 113, 51-59. [CrossRef]

10. Iezzi, S.; Padova, M.D.; Serra, C.; Caretti, G.; Simone, C.; Maklan, E.; Minetti, G.; Zhao, P.; Hoffman, E.P.; Puri, P.L.; et al. Deacetylase Inhibitors Increase Muscle Cell Size by Promoting Myoblast Recruitment and Fusion through Induction of Follistatin. Dev. Cell 2004, 6, 673-684. [CrossRef]

11. Cui, S.S.; Yang, C.P.; Bowen, R.C.; Bai, O.; Li, X.M.; Jiang, W.; Zhang, X. Valproic Acid Enhances Axonal Regeneration and Recovery of Motor Function after Sciatic Nerve Axotomy in Adult Rats. Brain Res. 2003, 975, 229-236. [CrossRef]

12. Grabiec, A.M.; Krausz, S.; de Jager, W.; Burakowski, T.; Groot, D.; Sanders, M.E.; Prakken, B.J.; Maslinski, W.; Eldering, E.; Tak, P.P.; et al. Histone Deacetylase Inhibitors Suppress Inflammatory Activation of Rheumatoid Arthritis Patient Synovial Macrophages and Tissue. J. Immunol. 2010, 184, 2718-2728. [CrossRef]

13. De Caro, C.; Di Cesare Mannelli, L.; Branca, J.J.V.; Micheli, L.; Citraro, R.; Russo, E.; De Sarro, G.; Ghelardini, C.; Calignano, A.; Russo, R. Pain Modulation in WAG/Rij Epileptic Rats (A Genetic Model of Absence Epilepsy): Effects of Biological and Pharmacological Histone Deacetylase Inhibitors. Front. Pharmacol. 2020, 3, 11. [CrossRef]

14. Kozubek, A.; Tyman, J.H.P. Resorcinolic Lipids, the Natural Non-Isoprenoid Phenolic Amphiphiles and Their Biological Activity. Chem. Rev. 1999, 99, 1-26. [CrossRef]

15. Kushneruk, M.A.; Tugarova, A.V.; Il'chukova, A.V.; Slavkina, E.A.; Starichkova, N.I.; Bogatyrev, V.A.; Antoniuk, L.P. Factors Inducing Transition from Growth to Dormancy in Rhizobacteria Azospirillum Brasilense. Mikrobiologiia 2013, 82, 563-570. [CrossRef]

16. Arias, E.; González, J.; Peiró, J.M.; Oria, R.; Lopez-Buesa, P. Browning Prevention by Ascorbic Acid and 4-Hexylresorcinol: Different Mechanisms of Action on Polyphenol Oxidase in the Presence and in the Absence of Substrates. J. Food Sci. 2007, 72, C464-G470. [CrossRef]

17. Chhabra, R.S.; Huff, J.E.; Haseman, J.; Hall, A.; Baskin, G.; Cowan, M. Inhibition of Some Spontaneous Tumors by 4Hexylresorcinol in F344/N Rats and B6C3F1 Mice. Fundam. Appl. Toxicol. 1988, 11, 685-690. [CrossRef]

18. National Toxicology Program. NTP Toxicology and Carcinogenesis Studies of 4-Hexylresorcinol (CAS No. 136-77-6) in F344/N Rats and B6C3F1 Mice (Gavage Studies). Natl. Toxicol. Program. Tech. Rep. Ser. 1988, 330, 1-166.

19. Kim, S.G.; Lee, S.W.; Park, Y.W.; Jeong, J.H.; Choi, J.Y. 4-Hexylresorcinol Inhibits NF-kB Phosphorylation and has a Synergistic Effect with Cisplatin in KB Cells. Oncol. Rep. 2011, 26, 1527-1532. [CrossRef] [PubMed]

20. Kim, S.G.; Kim, A.S.; Jeong, J.H.; Choi, J.Y.; Kweon, H. 4-Hexylresorcinol Stimulates the Differentiation of SCC-9 Cells through the Suppression of E2F2, E2F3 and Sp3 Expression and the Promotion of Sp1 Expression. Oncol. Rep. 2012, 28, 677-681. [CrossRef]

21. Kim, S.G.; Jeong, J.H.; Park, Y.W.; Song, J.Y.; Kim, A.S.; Choi, J.Y.; Chae, W.S. 4-Hexylresorcinol Inhibits Transglutaminase-2 Activity and has Synergistic Effects Along with Cisplatin in KB Cells. Oncol. Rep. 2011, 25, 1597-1602. [CrossRef]

22. Kweon, H.Y.; Kim, S.G.; Choi, J.Y. Inhibition of Foreign Body Giant Cell Formation by 4-Hexylresorcinol through Suppression of Diacylglycerol Kinase Delta Gene Expression. Biomaterials 2014, 35, 8576-8584. [CrossRef] [PubMed]

23. Ahn, J.H.; Kim, S.G.; Kim, M.K.; Kim, D.W.; Lee, J.H.; Seok, H.; Choi, J.Y. Topical Delivery of 4-Hexylresorcinol Promotes Wound Healing via Tumor Necrosis Factor- $\alpha$ Suppression. Burns 2016, 42, 1534-1541. [CrossRef] [PubMed]

24. Kim, S.G. Immunomodulation for Maxillofacial Reconstructive Surgery. Maxillofac. Plast. Reconstr. Surg 2020, 42, 5. [CrossRef] [PubMed]

25. Kim, M.K.; Yoon, C.S.; Kim, S.G.; Park, Y.W.; Lee, S.K. Effects of 4-Hexylresorcinol on Protein Expressions in RAW 264.7 Cells as Determined by Immunoprecipitation High Performance Liquid Chromatography. Sci. Rep. 2019, 9, 3379. [CrossRef] [PubMed] 
26. Kim, D.W.; Jo, Y.Y.; Garagiola, U.; Choi, J.Y.; Kang, Y.J.; Oh, J.H.; Kim, S.G. Increased Level of Vascular Endothelial Growth Factors by 4-Hexylresorcinol is Mediated by Transforming Growth Factor- $\beta 1$ and Accelerates Capillary Regeneration in the Burns in Diabetic Animals. Int. J. Mol. Sci. 2020, 21, 3473. [CrossRef] [PubMed]

27. Furumai, R.; Komatsu, Y.; Nishino, N.; Khochbin, S.; Yoshida, M.; Horinouchi, S. Potent Histone Deacetylase Inhibitors Built from Trichostatin A and Cyclic Tetrapeptide Antibiotics Including Trapoxin. Proc. Natl. Acad. Sci. USA 2001, 98, 87-92. [CrossRef]

28. Kim, M.K.; Kim, S.G.; Lee, S.K. 4-Hexylresorcinol-Induced Angiogenesis Potential in Human Endothelial Cells. Maxillofac. Plast. Reconstr. Surg 2020, 42, 23. [CrossRef] [PubMed]

29. Kim, Y.S.; Kim, D.W.; Kim, S.G.; Lee, S.K. 4-Hexylresorcinol-Induced Protein Expression Changes in Human Umbilical Cord Vein Endothelial Cells as Determined by Immunoprecipitation High-Performance Liquid Chromatography. PLoS ONE 2020, 15, e0243975. [CrossRef]

30. Xu, W.S.; Parmigiani, R.B.; Marks, P.A. Histone Deacetylase Inhibitors: Molecular Mechanisms of Action. Oncogene 2007, 26, 5541-5552. [CrossRef]

31. Huang, W.; Zhao, S.; Ammanamanchi, S.; Brattain, M.; Venkatasubbarao, K.; Freeman, J.W. Trichostatin A Induces Transforming Growth Factor Beta Type II Receptor Promoter Activity and Acetylation of Sp1 by Recruitment of PCAF/p300 to a Sp1.NF-Y Complex. J. Biol. Chem. 2005, 280, 10047-10054. [CrossRef]

32. Martin-Gallausiaux, C.; Béguet-Crespel, F.; Marinelli, L.; Jamet, A.; Ledue, F.; Blottière, H.M.; Lapaque, N. Butyrate Produced by Gut Commensal Bacteria Activates TGF-Beta1 Expression Through the Transcription Factor SP1 in Human Intestinal Epithelial Cells. Sci. Rep. 2018, 8, 9742. [CrossRef]

33. Kim, M.S.; Kwon, H.J.; Lee, Y.M.; Baek, J.H.; Jang, J.E.; Lee, S.W.; Moon, E.J.; Kim, H.S.; Lee, S.K.; Chung, H.Y.; et al. Histone Deacetylases Induce Angiogenesis by Negative Regulation of Tumor Suppressor Genes. Nat. Med. 2001, 7, 437-443. [CrossRef]

34. Jo, Y.Y.; Kim, D.W.; Choi, J.Y.; Kim, S.G. 4-Hexylresorcinol and Silk Sericin Increase the Expression of Vascular Endothelial Growth Factor via Different Pathways. Sci. Rep. 2019, 9, 3448. [CrossRef]

35. Lagger, G.; O'Carroll, D.; Rembold, M.; Khier, H.; Tischler, J.; Weitzer, G.; Schuettengruber, B.; Hauser, C.; Brunmeir, R.; Jenuwein, T.; et al. Essential Function of Histone Deacetylase 1 in Proliferation Control and CDK Inhibitor Repression. EMBO J. 2002, 21, 2672-2681. [CrossRef] [PubMed]

36. Bhaskara, S.; Chyla, B.J.; Amann, J.M.; Knutson, S.K.; Cortez, D.; Sun, Z.W.; Hiebert, S.W. Deletion of Histone Deacetylase 3 Reveals Critical Roles in S Phase Progression and DNA Damage Control. Mol. Cell 2008, 30, 61-72. [CrossRef]

37. Yi, W.; Liu, T.; Gao, X.; Xie, Y.; Liu, M. 4-Hexylresorcinol Inhibits Osteoclastogenesis by Suppressing the NF-kB Signaling Pathway and Reverses Bone Loss in Ovariectomized Mice. Exp. Ther. Med. 2021, 21, 354. [CrossRef] [PubMed] 